\title{
Predicting buffelgrass survival across a geograph- ical and environmental gradient
}

\author{
FERNANDO A. IBARRA-F., JERRY R. COX, MARTHA H. MARTIN-R., TODD A. CROWL \\ AND CHRISTOPHER A. CALL
}

\begin{abstract}
Ibarra-F, and Martin-R. are graduate students, Range Science Department, Utah State University and USDAAgricultural Research Service, Forage and Range Research Laboratory, Utah State University, Logan 84322-6300. Borh are permanently stationed at Centro de Investigaciones Pecuaries del Estato de Sonora, Apdo Postal 1754, Hermosillo, Sonora, Mexico.; Cox is resident director of research and range extension specialist, Texas A\&M University, Agricultural Research and Extension Center, P.O. Box 1658, Vernon 76385. When this research was initiated, Cox was a range scientist with USDA-Agricultural Research Senvice in Tucson, Ariz and Logan, Ut.; Crowl is assistant professor, Ecolagy Center, Department of Fisheries and Wildlife and Watershed Sciences Unit. Utah State University, Logan 84322-5210.; and Call is associate professor, Range Science Department, Utah State University, Logan 84322-5230.
\end{abstract}

\begin{abstract}
This research was designed to identify relationships between $T$ $\mathbf{4 4 6 4}$ buffelgrass (Cenchrus ciliaris L.) survival and climatic and soil characteristics. At 167 buffelgrass seeding sites in North America we collected climatic and soils data where the grass: 1) persisted over time and increased in area covered (spreads), 2) persisted over time but does not increase in area covered (persists), and 3) declined over time and all plants eventually died (dies). At $\mathbf{3 0}$ sites in Kenya we collected climatic and soils data in the area where $T-4464$ seed was originally collected. Only total soil nitrogen and organic carbon differed among survival regimes. Total soil nitrogen and organic carbon concentrations were least where buffelgrass spreads, intermediate where the grass persists and greatest where the grass dies. To predict buffelgrass survival among the 3 survival regimes, and between areas where the grass spreads or dies, we used discriminant function analyses. A model including organic carbon, total soil nitrogen, sand, clay, potassium and cation exchange capacity correctly classified $78 \%\left(r^{2}=0.8\right)$ of the seeding sites in the 3 survival regimes. A model including sand, total soil nitrogen, calcium, mean minimum temperature in the coldest month, annual pre-

The authors acknowledge the financial support provided by USDA-Agricultural Research Service (Drs. Plowman, Knipling and Child). We thank Dr. N.J. Chanerton (USDA-ARS) for laboratory facilities, Drs. Gary Richardson (USDAARS) and D.V. Sisson (Utah State University) for statistical advice. We also appreciate support and financial assistance provided by Consejo Nacional de Ciencia y Tecnologia, the directors of Petronato del Centro de Investigaciones Pecuarias del Estado de Sonora. Instituto Nacional de Investigaciones Forestales y Agropecuarias, the Cattlemen Union and the State of Sonora. Appreciation is extended to Ing. Victor Jaramillo V., Director de Comision Tecrico Consultiva para la Determinacion de Coeficientes de Agostadero, and Ing. Rogelio Alcaraz-F., Alberto Navarro-C., Javier Arellanes-A., Carmen R. Lopez-A., and Marco A. Perez-L. for data collection. Drs. Roger E. Banner, Raymond W. Miller, Brien E. Norton, G. Allan Rasmussen and John C. Malechek provided encouragement and manuscript review.

Part of dissertation submitted by the senior author in partial fulfillment of a Ph.D. degree. Reprint requests should be sent to J.R. Cox. Cooperative investigations of the USDA-Agricultural Research Service and the Utah State Agricultural Experiment Station. Joumal paper 4560.

Manuseript accepted 19 Apr. 1994.
\end{abstract}

cipitation and winter precpitation correctly classified $88 \%$ $\left(r^{2}=0.8\right)$ of the seeding sites between spreads and dies. Survival regime selection prior to brush control, seedbed preparation and sowing will reduce planting failure probabilities, soil erosion and economic losses, and enhance long-term beef production.

Key Words: Cenchrus Ciliaris L., range seeding, climate, soil nutrients, Mexico, Texas, Kenya

Buffelgrass (Cenchrus ciliaris L.), a perennial warm-season bunchgrass is native to Africa, Asia, and the Middle East (Bogdan 1961, Khan and Zarif 1982, Holt 1985, Mannetje and Jones 1990). The species predominates where surface soils are sandy and annual precipitation ranges from 200 to $1,200 \mathrm{~mm}$ (Cox et al. 1988).

Buffelgrass seed collected in the Turkana Desert, northcentral Kenya, was sown in Texas during the 1940's and resulting stands were evaluated for seedling establishment, forage production and persistence (Holt 1985). Scedlings from seed sown in summer were easily established and mature plants survived winter in south Texas.

In 1949, the USDA-Soil Conservation Service informally released T-4464 buffelgrass (Holt 1985). T-4464 plants were established at most planting sites in south Texas, and between 1949 and 1985, the grass was established on over 4 million ha (Cox et al. 1988). Seed was transported to Mexico and successfully established along the eastern and western coasts (Cota and Johnson 1975, Molina ct al. 1976, Agostini et al. 1981, Hanselka 1985). Land managers assumed that plant populations would persist under a variety of climatic and soil conditions. However, spread of stands occurred only at a few locations. At other seeded sites, plant stands have persisted but have not spread or have disappeared. Similar observations have been reported in Africa (Brzostowski 1962, Brzostowski and Owen 1964, DuToit et al. 1976), Australia (Wilson 1964, Coaldrake and Russell 1969, Ebersohn 1970, Anderson 1974, Hacker 1989, Silcock and Smith 1990, Walker and Weston 1990) and the United States (Ball 
1964, Gonzales and Dodd 1979, Gonzales and Latigo 1981).

Because T -4464 was originally collected in northcentral Kenya, and spreads most frequently in south Texas and northwest Mexico, we hypothesized that climate and soils around the original collection site and where the plant spreads in North America were more similar than where the plant fails to spread or dies. If the hypothesis is true, then climatic and soil information from south Texas, northwestern Mexico and northcentral Kenya can be used worldwide to select seeding sites where buffelgrass has a high probability for establishment and persistence.

If range reseeding continues to be an economical alternative in reclamation of degraded rangeland, then information which increases success in species establishment and persistence is needed. The objectives of this study were i) to identify climatic and soil properties which determine where the species either 1) persists over time, and increases in area coverage (spreads), 2) persists over time but does not increase in area coverage (persists) or 3) declines over time and all plants eventually die (dies); and ii) to develop predictive models that can be used by land managers and ranchers to select seeding sites where buffelgrass has a high probability for establishment and persistence.

\section{Methods and Materials}

\section{Study Site Selection}

Historical records and journals were examined to determine where $T-4464$ seed was collected in Africa and where the plant had been established in North America (Fig. 1). Rangeland conservationists in Keny'a, Texas and Mexico identified the original seed collection area or located and aged sites where the grass survived for 10 or more years. Together we selected 167 buffelgrass seeding sites in North America, and 30 sites around the area where T-4464 seed was collected in northcentral Kenya. Seeding site sizes varied from 50 to $500 \mathrm{ha}$, and approximately $95 \%$ of the annual biomass production was harvested by domestic livestock and wildlife. Forty-seven stands were located in northwest Mexico, 59 in northeast Mexico, 27 in south Texas, and 34 in southeast Mexico. Northwest Mexico sites were between the settlements of Hermosillo and Mazatlan; southeast sites were within the Yucatan Peninsula; and northeast Mexico and south Texas sites were between Ciudad Victoria, Tamaulipas and Monterrey, Nuevo Leon, Mexico, and San Antonio and Laredo, Tex. (Fig. 1).

Planting sites in northwest Mexico were at low elevations between the Sierra Madre Occidental and the Gulf of California Plain (22 $30^{\prime}$ and $31^{\circ} 00^{\prime} \mathrm{N}$ lat.; and $105^{\circ} 30^{\prime}$ and $111^{\circ} 20^{\prime} \mathrm{W}$ long.). Climate varies from tropical dry, semitropical subdesertic, subtropical very dry, to semitropical desertic (FAO-UNESCO 1975a). Dominant soils are Yermosols and Regosols with lithic Yermosols, lithic Xerosols, lithic Kastanozems, Lithosols, lithic orthic Luvisols, Fluvisols and Gleysols.

Sites in northeast Mexico and south Texas were between the Gulf of Mexico Coastal Plain, the Rio Grande Plain, and the Sierra Oriental foothills (23 $00^{\prime}$ and $28^{\circ} 30^{\prime} \mathrm{N}$ lat.; and $97^{\circ} 50^{\prime}$ and $100^{\circ} 00^{\prime} \mathrm{W}$ long.). Climate within this area varies from humid to very dry subtropical, and rather humid to very dry warm temperate to semitropical subdesertic (FAO-UNESCO 1975a, 1975b). Dominant soils are luvic and calcic Kastanozems, Rendzinas, luvic Phaeozems, pellic Vertisols, eutric Cambisols, eutric Fluvisols, eutric Gleysols and Regosols.

Sites in southeast Mexico were within the Yucatan Peninsula

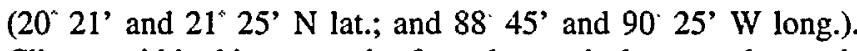
Climate within this area varies from dry tropical to very dry tropical (FAO-UNESCO 1975a). Dominant soils are Rendzinas, pellic Vertisols, Lithosols, eutric Nitosols, lithic chromic Luvisols, lithic chromic Cambisols and shallow Miocene Histosols.

Sites in northcentral Kenya were west of Lake Turkana; between the Ethiopian Highlands and the East African Plateaus $\left(0^{\circ} 30^{\prime}\right.$ and $4^{\circ} 30^{\prime} \mathrm{N}$ lat.; and $35^{\circ} 45^{\prime}$ and $36^{\circ} 20^{\prime} \mathrm{W}$ long.). Climate in this area varies from semiarid tropical to hot tropical desert (FAO-UNESCO 1977). Dominant soils are eutric and calcaric Regosols, Xerisols, Fluvisols, Vertisols and Solonchaks.

Site elevations vary from 20 to $700 \mathrm{~m}$ in North America, and from 15 to $580 \mathrm{~m}$ in Kenya. Slopes range from 2 to $10 \%$. Precipitation ranges from 200 to $1,200 \mathrm{~mm}$ in North America, and is bimodally distributed in either spring and summer or winter and summer. In Kenya, precipitation ranges from 200 to 400 $\mathrm{mm}$, and is bimodally distributed in early and late summer.

\section{Study Site Classification}

At North American seeding sites the plant stabilized at one of the following end points: 1) plants survived in the seeded area and new plants established naturally from seed outside the planting area (spreads), 2) plants survived in the seeded area but did not spread outside the seeded area (persists), and 3) plants persisted in the seeded area for 10 or more years, and over time all plants eventually died (dies). Where T-4464 spreads, densities inside and outside the seeded area exceed 1 plant $\mathrm{m}^{-2}$. Where the

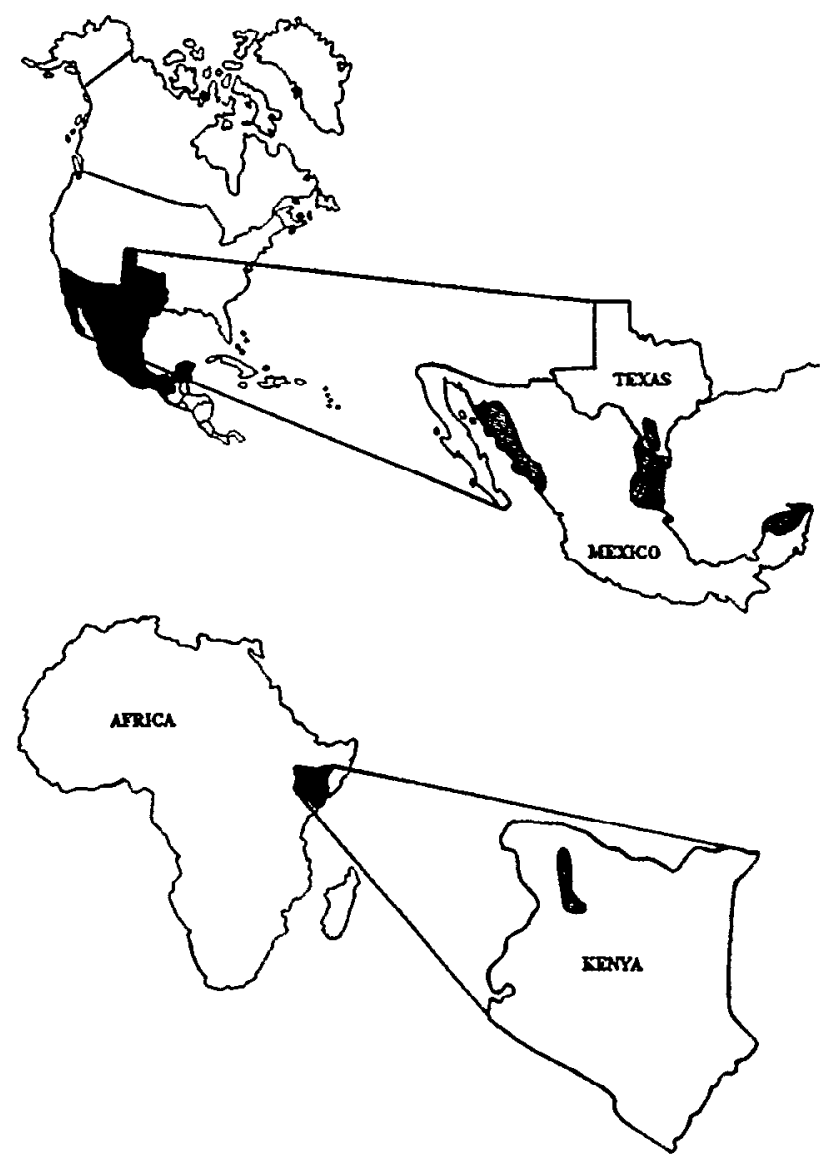

Fig. 1. Location of buffelgrass (Cenchrus ciliaris) sampling sites. 
Table 1. Soil textural classes at buffelgrass seeding sties where the plant either spreads ( 82 sites), persists ( 50 sites), or dies (35 sites) in Mexico and south Texas.

\begin{tabular}{lccc}
\hline \hline \multirow{2}{*}{ Textural Class } & & Survival Regime & \\
\cline { 2 - 4 } & Spreads & Persists & Dies \\
\hline Sand & 6 & 1 & - \\
Loany sand & 12 & 5 & - \\
Sandy loam & 21 & 4 & 2 \\
Sandy clay loam & 21 & 7 & - \\
Loam & 7 & 4 & 8 \\
Clay loam & 7 & 13 & 15 \\
Clay & 8 & 13 & 6 \\
Silty clay loam & - & 3 & 1 \\
Silty clay & - & - & 3 \\
& - & - & -55 \\
TOTAL & 82 & 50 &
\end{tabular}

plant persists, densities inside the seeded area exceed 1 plant $\mathrm{m}^{-2}$, and densities outside the seeded area were $<1$ plant in $4 \mathrm{~m}^{-2}$. Where the plant dies no plants were observed inside or outside the seeded area. Based on these criteria, seeding sites in Mexico and Texas were divided among 3 survival regimes: 1) 82 sites were classified in survival regime 1 (spreads), 2) 50 sites were classified in survival regime 2 (persists) and 3) 35 sites were classified in survival regime 3 (dies).

\section{Soil Sampling}

Soils were collected at $0-10,10-20$, and $20-30 \mathrm{~cm}$ depths near the crown of 3 buffelgrass plants or in open areas where buffelgrass plants died. Three soils samples were collected at each soil depth. Composited samples were air dried, passed through a 2mm sieve and thoroughly mixed. Duplicate subsamples from each composite were analyzed for particle-size distribution (Day 1950 ), $\mathrm{pH}$ (saturated paste), electrical conductivity of the saturated extract and cation exchange capacity (U.S. Salinity Laboratory
Staff 1954), ammonium acetate soluble cations including calcium, potassium, sodium and magnesium, total nitrogen, organic carbon, (Jackson 1958) and available phosphorus was extracted with $\mathrm{NAHCO}_{3}$ (Olsen and Sommers 1982).

\section{Climatic Parameters}

Climatic data were collected at or from nearby areas where seed was orginially collected, and where plants either spread, persisted or died. Climatic reporting stations were selected based upon 1) topographic similarities between reporting stations and the 3 survival regimes plus areas where seed were collected, and 2) having 20 or more years of continuous records which corresponded with actual planting and subsequent growing years. Climatic data are summarized in the following categories: 1) winter 2) summer and 3) total precipitation, and mean monthly 4) maximum and 5) minimum temperatures. We selected 17 stations in northwest Mexico, 25 stations in northeast Mexico and south Texas, 10 stations in southeast Mexico, and 7 stations in northcentral Kenya (Agroclimatological Data for Africa 1984, Climatography of Mexico 1982, Climatography of the United States 1985).

\section{Data Analysis}

Because site selection was not random and site numbers within survival regimes were unequal, the treatment variances were compared. A Hartley test (Zar 1984) was used to determine differences $(P \leq 0.05)$ among survival regimes for each weather parameter and soil component. When significant differences existed, a $\log (\mathrm{X}+1)$ transformation was performed. All measured parameters were compared across survival regimes using a multiple-analysis-variance (MANOVA) test. Univariate comparisons were adjusted according to the Bon Ferroni correction (Winer 1971).

A mean and coefficient of variation were generated for each soil component using data from the 3 depths at each sampling

Table 2. Surface soil $(0-10 \mathrm{~cm})$ means and standard deviations for particle-size distribution and selected chemical properties at sites where buffelgrass either spreads, persists or dies at planting sites in south Texas and Mexico, and where the seed was originally collected in northcentral Kenya. An asterisk $\left(^{*}\right)$ indicates a significant difference $(P \leq 0.05)$ among variances in the 3 survival regimes.

\begin{tabular}{|c|c|c|c|c|c|}
\hline \multirow[b]{2}{*}{$\begin{array}{l}\text { Soil } \\
\text { Properties }\end{array}$} & \multicolumn{3}{|c|}{ Survival Regime } & \multirow[b]{2}{*}{$\begin{array}{c}\text { Hartley } \\
\text { test }\end{array}$} & \multirow[b]{2}{*}{ Kenya } \\
\hline & Spreads & Persists & Dies & & \\
\hline Sand $(C, C)$ & $61.0 \pm 20.2$ & $44.9 \pm 24.6$ & $35.3 \pm 15.4$ & NS & $82.0 \pm 14.8$ \\
\hline Silt $(\%)$ & $17.5 \pm 10.8$ & $24.1 \pm 13.2$ & $32.3 \pm 7.2$ & NS & $11.9 \pm 9.2$ \\
\hline Clay $(C)$ & $21.5 \pm 11.6$ & $31.0 \pm 15.3$ & $32.4 \pm 11.2$ & NS & $6.1 \pm 6.1$ \\
\hline Silt + clay $(\%)$ & $39.0 \pm 18.7$ & $55.1 \pm 24.3$ & $64.7 \pm 16.2$ & NS & $18.0 \pm 14.8$ \\
\hline $\mathrm{pH}$ & $7.8 \pm 0.5$ & $7.6 \pm 0.6$ & $7.5 \pm 0.4$ & NS & $8.1 \pm 0.5$ \\
\hline Electrical conductivity $\left(\mathrm{ds} \mathrm{m}^{-3}\right.$ ) & $0.3 \pm 0.2$ & $0.3 \pm 0.1$ & $0.3 \pm 0.1$ & NS & $0.2 \pm 0.1$ \\
\hline Total nitrogen $(\%)$ & $0.1 \pm 0.1$ & $0.3 \pm 0.2$ & $0.5 \pm 0.3$ & * & $0.1 \pm 0.1$ \\
\hline Organic carbon $(S)$ & $0.9 \pm 0.7$ & $2.6 \pm 2.9$ & $4.4 \pm 3.6$ & * & $0.6 \pm 0.2$ \\
\hline Phosphorus (mg kg') & $10.6 \pm 11.9$ & $12.9 \pm 12.7$ & $10.0 \pm 22.3$ & NS & $17.2 \pm 9.2$ \\
\hline Cation exchange capacity $\left(\mathrm{cmol} \mathrm{kg}^{-1}\right)$ & $22.5 \pm 13.4$ & $38.1 \pm 24.4$ & $61.8 \pm 24.9$ & NS & $15.6 \pm 13.7$ \\
\hline Sodium $(\mathrm{cmol} \mathrm{kg}$ ) & $0.4 \pm 0.6$ & $0.4 \pm 0.4$ & $0.4 \pm 0.2$ & NS & $0.2 \pm 0.2$ \\
\hline Potussium (cmol $\mathrm{kg}^{-1}$ ) & $1.1 \pm 0.7$ & $1.9 \pm 1.3$ & $1.8 \pm 0.9$ & NS & $1.0 \pm 0.9$ \\
\hline Calcium (cmol kg') & $35.9 \pm 26.5$ & $42.0 \pm 23.0$ & $47.8 \pm 16.6$ & NS & $12.4 \pm 13.5$ \\
\hline Magnesium (cmol $\mathrm{kg}^{-1}$ ) & $1.9 \pm 1.5$ & $3.2 \pm 2.2$ & $3.7 \pm 2.5$ & NS & $2.1 \pm 1.6$ \\
\hline
\end{tabular}




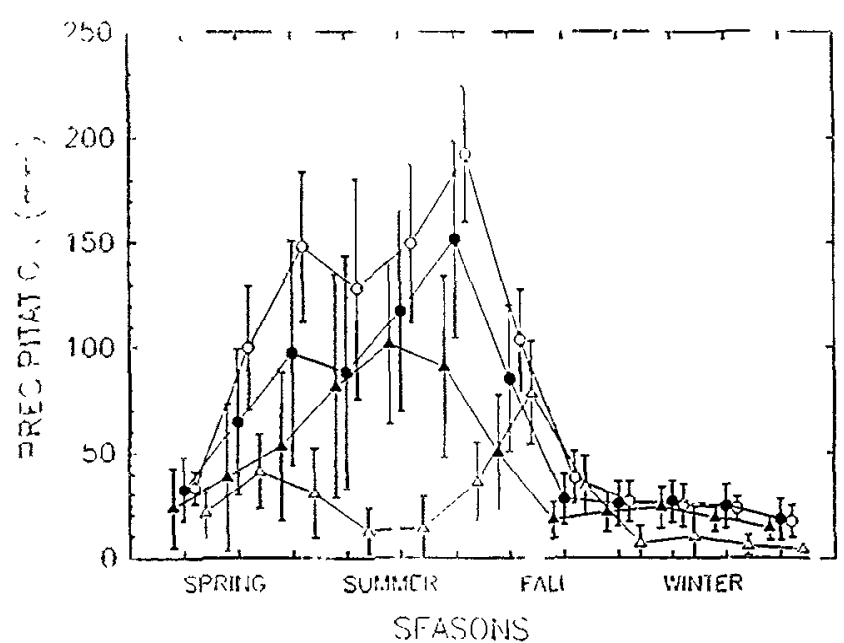

Fig 2. The variation in mean monthly precipitation distribution at buffelgrass seeding sites in North America and where seed was originally collected in Africa. Lines represent sites where the plant persists and spreads from a seeding $(\Delta)$, persists but does not spread from a seeding $(\bullet)$, dies $(0)$, and where seed were originally collected in northcentral Kenya $(\Delta)$.

site. Individual depth means, an overall depth mean, and the coefficient of variation were included in the analyses to generate predictive equations for the different buffelgrass survival regimes. Because climatic and soil variables are correlated, discriminant function analyses was used to select the best predictors of buffelgrass survival. In initial discriminate function analyses runs we included the 3 survival regimes. Because variable values in regime 2 frequently overlapped those in regimes 1 and 3 , we excluded regime 2 in the second model. Data from Kenya were not included in discriminate function analyses because different survival regimes were not assigned to sampling sites. Climatic and soil data from Kenya were included in order to compare conditions where the plant evolved with those of the 3 survival regimes in Mexico and Texas. Analyses were performed using the SAS statistical package for personal computers (SAS 1988).

\section{Results and Discussion}

\section{Soil Physical and Chemical Properties}

Where buffelgrass spreads in North America, soils are generally coarse-textured (Table 1). At 73\% of the sampling sites where the species spreads, textural classes are predominantly sandy. Where the species persists, $34 \%$ of the textural classes are sandy and $66 \%$ are silty or clayey. Where the species dies, $94 \%$ of the textural classes are either silty or clayey. On sandy and loamy soils in southeast Mexico, T-4464 dies because a shallow hardpan limits downward water movement and seasonal flooding saturates the soil profile. In Australia, poor soil aeration limits buffelgrass growth and survival (Humphreys 1967, Anderson 1972).

Of the measured soil chemical properties, only total nitrogen and organic carbon variances differed $(P \leq 0.05)$ among $T-4464$ survival regimes (Table 2). Total nitrogen and organic carbon quantities are least where the species spreads, intermediate where the species persists and greatest where the species dies. In northcentral Kenya, soils are coarser and less fertile than where the species has been planted in North America. However, chemical

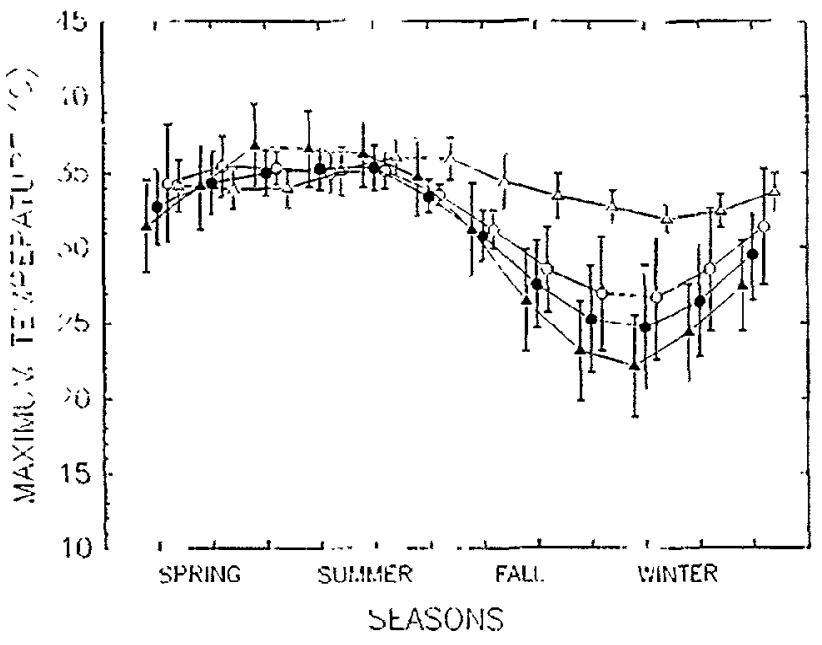

Fig. 3. The variation in mean monthly maximum temperatures at buffelgrass seeding sites in North American and where seed were originally collected in northcentral Kenya. Lines represent sites where the plant persists and spreads from a seeding $(\mathbf{A})$, persists but does not spread from a seeding $(\bullet)$, dies (o), and where seed were originally collected in northcentral Kenya $(\Delta)$.

and physical soil properties where the species evolved in Africa are similar to where the species spreads in North America; with the exception of available phosphorus, which is consistently higher in Kenya than North America. This verifies the hypothesis that soils in Kenya where T-4464 mother plants evolved are more similar to soils in North America where the plant spreads, than soils where plants either persist or die.

In Queensland, Australia the growth of buffelgrass plants on sandy red soils was delayed when available phosphorus $(0.01 \mathrm{~N}$ $\mathrm{H}_{2} \mathrm{SO}_{4}$ extractable) was less than $25 \mathrm{mg} \mathrm{kg}^{-1}$, and when available phosphorus was limiting few plants survived drought (Christie 1975) Where buffelgrass spreads in North America and evolved in Kenya, available soil phosphorus varied from 0.1 to $26.4 \mathrm{mg}$ $\mathrm{kg}^{-1}$, averaged $13.1 \mathrm{mg} \mathrm{kg}$, and seldom exceeded $16.5 \mathrm{mg} \mathrm{kg}^{-1}$. Low available soil phosphorus in North American soils may limit buffelgrass productivity (Molina et al. 1976, Gonzales and Dodd 1979, Gonzales and Latigo 1981) but concentrations below 0.1 $\mathrm{mg} \mathrm{kg}^{-1}$ do not appear to impact the plant's ability to either establish from seed or survive.

\section{Climatic Parameters}

In North America, buffelgrass spreads where annual precipitation amounts range from 330 to $550 \mathrm{~mm}$, and the species persists and dies when amounts range from 600 to $1,200 \mathrm{~mm}$ (Fig. 2). Buffelgrass seed from plants established on planted sites actively colonize adjacent nonplanted sites between Crystal City and Larado, Tex. and Carbo and Hermosillo, Mexico. At these locations, summer rainfall varies from 170 to $400 \mathrm{~mm}$ and winter rainfall varies from 10 to $285 \mathrm{~mm}$. Dry periods totaling 150 to 210 days occur in either winter or fall and spring, and mean maximum and minimum temperatures in the coldest month range between 24 and $32 \mathrm{C}$ (Fig. 3), and 5 and 15C (Fig. 4), respectively.

Annual precipitation in northcentral Kenya varies from 200 to $400 \mathrm{~mm}$, and is bimodally distributed in 2 summer growing seasons (Fig. 2). Mean minimum and maximum temperatures annu- 
Table 3. Disciminant function analyses statistics. Model I differentiates among sites where buffelgrass either spreads, persists or dies, and Model II differentiates between sites where the grass either spreads or dies.

\begin{tabular}{|c|c|c|c|c|}
\hline Parameter & $\mathrm{F}$ & $\mathbf{P}$ & Partial $R^{2}$ & Total $R^{2}$ \\
\hline & \multicolumn{2}{|c|}{ MODEL I } & & \\
\hline Sand $(\%)$ at $0-10 \mathrm{~cm}$ & 25.3 & 0.0001 & 0.6479 & 0.267 \\
\hline Total nitrogen $(\%)$ at $0-10 \mathrm{~cm}$ & 13.9 & 0.0001 & 0.80 & 0.434 \\
\hline Clay $(c)$ at $20-30 \mathrm{~cm}$ & 8.2 & 0.0004 & 0.6146 & 0.539 \\
\hline Organic carbon $(c)$ at $0-10 \mathrm{~cm}$ & 6.3 & 0.0025 & 0.7934 & 0.622 \\
\hline Potassium (cmol $\mathrm{kg}^{\mathrm{N}}$ ) at $0-30 \mathrm{~cm}$ & 5.1 & 0.0072 & 0.4476 & 0.691 \\
\hline \multirow[t]{2}{*}{ CEC-CV $(\mathrm{cmol} \mathrm{kg})$ at $0-30 \mathrm{~cm}^{3}$} & 3.0 & 0.0222 & 0.0994 & 0.744 \\
\hline & \multicolumn{2}{|c|}{ MODEL II } & & \\
\hline Total nitrogen $(C)$ at $0-10 \mathrm{~cm}$ & 30.7 & 0.0001 & 0.9488 & 0.242 \\
\hline Mean min. temperature $\left({ }^{\circ} \mathrm{C}\right)$ & 21.1 & 0.0001 & 0.7348 & 0.422 \\
\hline Sand $(C)$ at $0-10 \mathrm{~cm}$ & 18.9 & 0.0001 & 0.6517 & 0.586 \\
\hline Winter precipitation (mm) & 15.5 & 0.0002 & 0.5144 & 0.725 \\
\hline Total precipitation (mm) & 9.4 & 0.0028 & 0.8225 & 0.814 \\
\hline Sand $(C)$ at $10-20 \mathrm{~cm}$ & 8.0 & 0.0056 & 0.9447 & 0.891 \\
\hline Calcium $(\mathrm{cmol} \mathrm{kg}$ ) at $10-20 \mathrm{~cm}$ & 6.4 & 0.0129 & 0.4059 & 0.954 \\
\hline
\end{tabular}

' $\mathrm{CEC}=$ Cation exchange capacily; $\mathrm{CV}=$ Coefficient of variation

ally vary from 21 to $24 \mathrm{C}$ and 31 to $36 \mathrm{C}$ (Figs. 3 and 4), respectively, and buffelgrass growth occurs whenever soil moisture is available (Cox et al. 1988). Temperature extremes in Texas and Mexico differ from those in northcentral Kenya but rainfall amount and distribution where the plant evolved in Africa are more similar to where the plant spreads, than where the plant persists or dies in North America.

\section{Model Development}

Comparisons of log-transformed means among soil depths within the 3 survival regimes indicate the importance of cation exchange capacity, organic carbon, total nitrogen, potassium, sand, silt, clay, silt plus clay, and magnesium when selecting buffelgrass seeding sites. Climatic parameters influencing seedling persistence and spread were mean minimum temperature in the coldest month, summer precipitation, and total annual precipitation.

In Model I, plant survival among the 3 survival regimes was influenced by sand $(\%)$ at $0-10 \mathrm{~cm}$, total nitrogen $(\%)$ at $0-10 \mathrm{~cm}$, clay $(\%)$ at $20-30 \mathrm{~cm}$, organic carbon $(\%)$ at $0-10 \mathrm{~cm}$, potassium $(\mathrm{cmol} \mathrm{kg}$ ) at $0-30 \mathrm{~cm}$, and the cation exchange capacity $(\mathrm{cmol}$ $\mathrm{kg}-1$ ) coefficient of variation at $0-30 \mathrm{~cm}$ (Tables 3 and 4). The combined parameter group classified $78 \%$ of the seeding sites in the correct survival regime (overall Wilk's lambda $=0.39$, composite $r^{2}=0.80$ ). Predictive equations for the 3 survival regimes were:

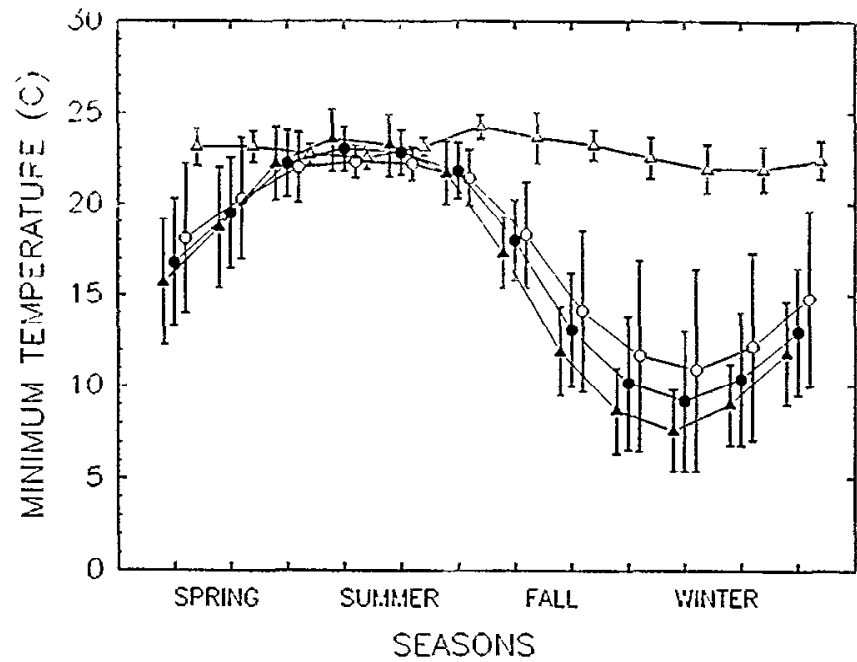

Fig. 4. The variation in mean monthly minimum temperatures at buffelgrass seeding sites in North America and where seed were originally collected in northcentral Africa. Lines represent sites where the plant persists and spreads from a seeding (A), persists but does not spread from a seeding ( $\bullet$, dies (o), and where seed were originally collected in northcentral Kenya $(\Delta)$.

spreads $=-3.01+1.61$ (sand) +1.0 (total nitrogen $)+0.84$ (clay) 1.0 (organic carbon) - 0.16 (potassium) -0.05 (cation exchange capacity - coefficient of variation);

persists $=+2.90-1.09$ (sand) -4.77 (total nitrogen) -0.59 (clay) +1.03 (organic carbon) +0.82 (potassium) -0.16 (cation exchange capacity - coefficient of variation);

dies $=\quad+1.11-0.52$ (sand) +3.77 (total nitrogen $)-0.25$ (clay) - 0.02 (organic carbon) -0.66 (potassium) +0.21 (cation exchange capacity - coefficient of variation).

Due to data variability and overlapping values between survival regimes 1 and 2, and between survival regimes 2 and 3 we developed Model II to differentiate between the spreads and dies regimes (Table 5). Plant survival between the 2 regimes was influenced by total nitrogen at $0-10 \mathrm{~cm}$, mean minimum temperature in the coldest month $(\mathrm{C})$, sand $(\%)$ at $0-10 \mathrm{~cm}$, winter precipitation (mm), total annual precipitation $(\mathrm{mm})$, sand (\%) at $10-$ $20 \mathrm{~cm}$, and calcium ( $\mathrm{cmol} \mathrm{kg}^{-1}$ ) at $10-20 \mathrm{~cm}$. The combined parameter group classified $88 \%$ of the seeding sites in the correct survival regime (overall Wilk's lambda $=0.34$, composite $\mathrm{r}^{2}=0.82$ ). Predictive equations for the 2 survival regimes were:

spreads $=-0.82-3.22$ (total nitrogen) +1.37 (mean minimum temperature in the coldest month) +2.41 (sand at $0-10$

Table 4. Means and standard deviations for parameters in Model I that discriminate among seeding sites where buffelgrass either spreads, persists or dies.

\begin{tabular}{lrrr}
\hline & & Survival Regime & \multicolumn{1}{c}{ Dies } \\
\hline Parameter & \multicolumn{1}{c}{ Spreads } & Persists & $37.28 \pm 16.4$ \\
Sand $(S)$ at $0-10 \mathrm{~cm}$ & $63.09 \pm 18.7$ & $41.61 \pm 24.4$ & $0.52 \pm 0.34$ \\
Total nitrogen $(\%)$ at $0-10 \mathrm{~cm}$ & $0.12 \pm 0.11$ & $0.25 \pm 0.23$ & $34.59 \pm 16.9$ \\
Clay $(C)$ at $20-30 \mathrm{~cm}$ & $26.90 \pm 12.8$ & $2.78 \pm 17.6$ & $4.10 \pm 3.25$ \\
Organic carbon $(\%)$ at $0-10 \mathrm{~cm}$ & $0.84 \pm 0.55$ & $1.39 \pm 0.83$ & $1.38 \pm 0.93$ \\
Potassium $\left(\mathrm{cmol} \mathrm{kg}^{\prime}\right)$ at $0-30 \mathrm{~cm}$ & $0.76 \pm 0.51$ & $9.71 \pm 7.45$ & $10.49 \pm 8.29$ \\
CEC-CV (cmol kg) at $0-30 \mathrm{~cm}^{1}$ & $14.54 \pm 14.5$ & & \\
\hline
\end{tabular}

' $\mathrm{CEC}=$ Cation exchange capacity; $\mathrm{CV}=$ Coefficient of variation 
Table 5 Means and standard deviations for parameters in Model II that discriminate between seeding sites where buffelgrass either spreads or dies.

\begin{tabular}{lcc}
\hline \hline & \multicolumn{2}{c}{ Survival Regime } \\
\cline { 2 - 3 } Parameter & Spreads & Dies \\
\hline Total nitrogen $(\%)$ at $0-10 \mathrm{~cm}$ & $0.12 \pm 0.11$ & $0.52 \pm 0.34$ \\
Mean Min. Temperature $\left({ }^{\circ} \mathrm{C}\right)$ & $7.89 \pm 2.44$ & $13.37 \pm 4.88$ \\
Sand $(\%)$ at $0-10 \mathrm{~cm}$ & $63.09 \pm 18.7$ & $37.28 \pm 16.4$ \\
Winter precipitation $(\mathrm{mm})$ & $165.15 \pm 60.1$ & $158.92 \pm 69.2$ \\
Total Precipitation $(\mathrm{mm})$ & $535.80 \pm 130$ & $928.64 \pm 260$ \\
Sand $(\%)$ at $10-20 \mathrm{~cm}$ & $59.50 \pm 20.1$ & $38.09 \pm 17.9$ \\
Calcium $(\mathrm{cmol} \mathrm{kg-1)}$ ) at $10-20 \mathrm{~cm}$ & $38.24 \pm 27.1$ & $45.80 \pm 20.2$ \\
\hline
\end{tabular}

$\mathrm{cm})+0.88$ (winter precipitation) -1.21 (total precipitation) -1.38 (sand at $10-20 \mathrm{~cm})+0.20$ (calcium)

dies $=+1.82+3.22$ (total nitrogen) -1.37 (mean minimum temperature in the coldest month) -2.41 (sand at $0-10 \mathrm{~cm}$ ) 0.80 (winter precipitation) +1.21 (total precipitation) + 1.38 (sand at $10-20 \mathrm{~cm}$ ) -0.20 (calcium).

Our inability to measure freezing temperature impact on exposed T -4464 crowns may account for predictive differences $(10 \%)$ between the 2 models. To illustrate freezing temperature importance, we will describe the fate of $4 \mathrm{~T}-4464$ seeding sites in southern Arizona (unpublished data, USDA-Agricultural Research Service, Tucson, Ariz.). Soils at the 4 sites were similar in depth and classified as sandy loam, elevations varied from 1,100 to $1,125 \mathrm{~m}$, and $3.0 \mathrm{~kg} \mathrm{ha}^{-1}$ of T-4464 seed (PLS) was sown on disk plowed fields in July 1980. In summer 1981, plant densities varied from 3 to 4 plants $\mathrm{m}^{-2}$, and all sites were heavily grazed in summer-fall 1981 through 1985 . Following a rapid drop in temperatures during mid-January 1986, plants at 2 sites died, and plants at 2 sites persisted. Where $\mathrm{T}-4464$ died, temperatures at the crown base varied from 3 to $5 \mathrm{C}$ for 4 hours. Where plants persisted, temperatures at the crown base varied form 3 to $5^{\circ} \mathrm{C}$ for 1.5 hours.

To generate predictions from discriminant function analyses models, all equations are solved using data from the potential seeding site. The prediction for a potential seeding site is from the equation where the solution is closest to 1.0. For example, if we solve for the 3 equations in Model I and generate values of $0.21,0.87$ and 0.01 for spreads, persists and dies, respectively, the model prediction is that $\mathrm{T}-4464$ would persist.

\section{Management Implications}

Many range seeding failures occurred because land managers did not appreciate the importance of climate and soil to species adaptation. To emphasize this point, Cox et al. (1988) summarized rangeland revegetation techniques most frequently used in the past 100 years. The most widely used procedure has been to: 1) chemically or mechanically reduce competition, 2) prepare a seedbed, 3) plant seed of as many species, accessions or cultivars as possible, and 4) hope for rain. In about 1 of every 10 attempts, plants were successfully established but it was not possible to predict planting success at another site or estimate plant adaptability because climate and soils were not compared among sites.

To determine the importance of climate and soil on T-4464 buffelgrass survival, we classified 167 seeding sites into 3 survival regimes. We conclude that planting success or failure can be predicted with selected climatic and soil parameters, and climatic and soil parameters where T-4464 seed was collected in northcentral Kenya are more similar to where the species spreads than where it persists or dies in North America. Our results are practical and easily used by land managers who wish to maximize plant survival, and minimize soil erosion and economic loss.

\section{Literature Cited}

Agostini, J.J., J.A. Morales, and D. Enkerlin. 1981. Yield and quality of two hybrids of buffelgrass (Cenchrus ciliaris) damaged by different populations of the spittlebug (Aneolamia albofascita) and mites (Prosapia simulans). (In Spanish). Agronomia 200:42-47.

Agroclimatological Data for Africa. 1984. Rome, Italy. Food and Agriculture Organization of the United Nations.

Anderson, E.R. 1972. Emergence of buffelgrass (Cenchrus ciliaris) from seed after flooding. Queensland J. Agr. Anim. Sci. 29:167-172.

Anderson, E.R. 1974. The reaction of seven Cenchrus ciliaris L. cultivars to flooding. Trop. Grassl. 8:33-40.

Ball, D.E. 1964. Range seeding - Introduced grasses on rootplowed land in the northwest Rio Grande Plain. J. Range Manage. 17:217-220.

Bogdan, A.B 1961. Breeding behavior of Cenchrus ciliaris in Kenya. East African Agr. and Forest. J. 26:241.

Brzostowski, H.W. 1962. Influence of $\mathrm{pH}$ and superphosphate on establishment of Cenchrus ciliaris from seed. Trop. Agr. Trin. 39:289-296

Brzostowski, H.W., and M.A. Owen. 1964. Botanical changes in a sown pasture. Trop Agr. Trin. 41:231-242.

Christie, E.K. 1975. A study of phosphorus nutrition and water supply on the early growth and survival of buffelgrass grown on a sandy red earth from southwest Queensland. Australian J. Exp. Agr. and Anim. Husb. 15:239. 249.

Climatography of Mexico. 1982. Mexico City, Mexico. Nat. Meteorol. Serv. (In Spanish).

Climatography of the United States. 1985. Ashville, N.C.: Nat. Oceanic and Atmospheric Admin.

Coaldrake, J.E., and M.J. Russell. 1969. Establishment and persistence of some legumes and grasses after ash seeding on newly bumt brigalow land. Trop. Grassl. 3:49-55.

Cota, A., and D. Johnson. 1975. Adaptation and production of ten perennial grass species in Sonora. (In Spanish). Pastizales-CI-MP-00I. Chihuahua, Mexico.

Cox, J.R., M.H. Martin-R, F.A. Ibarra-F, J.H. Fourie, N.F.G. Rethman, and D.G. Wilcox. 1988. The influence of climate and soils on the distribution of four African grasses. J. Range Manage. 41:127-139.

Day, P.R. 1950. Physical basis of particle size analysis by the hydrometer method. Soil Sci. 74:81-86.

Du Toit, J., J.W. Rabic, and J.O. Grunow. 1976. Nutrition and production studies on Cenchrus ciliaris L. cv. Molopo. Proc. Grassl. Soc. Sth. Afr. 8:107-115.

Ebersohn, J.P. 1970. Herbage production from native grasses and sown pastures in southwest Queensland. Trop. Grassl. 4:37-41.

FAO-UNESCO. 1975a. Food and Agricultural Organization of The United Nations. United Nations Educational, Scientific and Cultural Organization. Soil map of the world Vol. III, Mexico and Central America.

FAO-UNESCO. 1975b. Food and Agricultural Organization of The United Nations. United Nations Educational, Scientific and Cultural Organization. Soil map of the world Vol. II, North America.

FAO-UNESCO. 1977. Food and Agricultural Organization of The United Nations. United Nations Educational, Scientific and Cultural Organization. Soil map of the world Vol. VI, Africa.

Gonzalez, C.L., and J.D. Dodd. 1979. Production response of native and introduced grasses to mechanical brush manipulation, seeding, and fertilization. J. Range Manage. 32:305-309.

Gonzalez, C.L., and G.V. Latigo. 1981. Rootplowing, front-end stacking, and seeding effects on herbaceous plant species composition. J. Range Manage. 34:460-465.

Hacker, J. B. 1989. The potential for buffelgrass renewal from seed in 16year-old buffelgrass-siratro pastures in south-east Queensland. J. Appl. Ecol. 26:213-222.

Hanselka, C. W. 1985. Grazing management strategies for buffelgrass, p. 53- 
64. In: E.C.A. Runge, and J. L. Schuster (ed.), Buffelgrass: Adaptation, management and forage quality symposium: Texas Agr. Exp. Sta. MP1575. College Station, Tex.

Holt, E. C. 1985. Buffelgrass - A brief history, p. 1-5. In: E.C.A. Runge and J. L. Schuster (ed.), Buffelgrass: Adaptation, management and forage quality symposium, Texas Agr. Exp. Sta. MP-1575. College Station, Tex.

Humphreys, L. R. 1967. Buffelgrass (Cenchrus ciliaris) in Australia. Trop. Grassl. 1:123-134.

Jackson, M. L. 1958. Soil chemical analysis. Prentice-Hill Inc., Englewood Cliffs, N.J.

Khan, S. M., and R. M. Zarif. 1982. Enhancing range productivity through grass seeding in subtropical semiarid shrublands near Pashawar. Pakistan J. Forest. 32:89-94.

Mannetje. L. t', and R. M. Jones. 1990. Pasture and animal productivity of buffelgrass with siratro, lucerne or nitrogen fertilizer. Trop. Grassl. 24:269281.

Molina, S. I., T. R. Garza, and H. M. Torres. 1976. Beef production on guinea and buffelgrass with two fertilizer rates, during one year in Tizimin, Yucatan. (In Spanish). Tecnica Pecuaria en Mexico. 31:17-21.
Olsen, S. R., and L. E. Sommers. 1982. Phosphorus. In: A. L. Page (ed.), Methods of Soil Analysis, Part II. American Society of Agronomy. Madison, Wis.

SAS Institute Inc., 1988. SAS Procedures Guide, Release 6.03 Edition. SAS Institute Inc. Cary, N.C.

Silcock, R. G., and F. T. Smith. 1990. Viable seed retention under field conditions by westem Queensland pasture species. Trop. Grassl. 24:65-74.

U. S. Salinity Laboratory Staff. 1954. Diagnosis and improvement of saline and alkaline soils. USDA, Agr. Handbook 60. Washington, D.C.

Walker, B., and E. J. Weston. 1990. Pasture development in Queensland - A success story. Trop. Grassl. 24:257-268.

Wilson, R. G. 1964. Plowing buffel seedbeds on hard soils. Queensland Agr. J. 90:286-288.

Winer, B.J. 1971. Statistical Concepts in Experimental Design. McGrawHill, N.Y.

Zar, J. H. 1984. Biostatistical analysis. Prentice Hall, N.J.

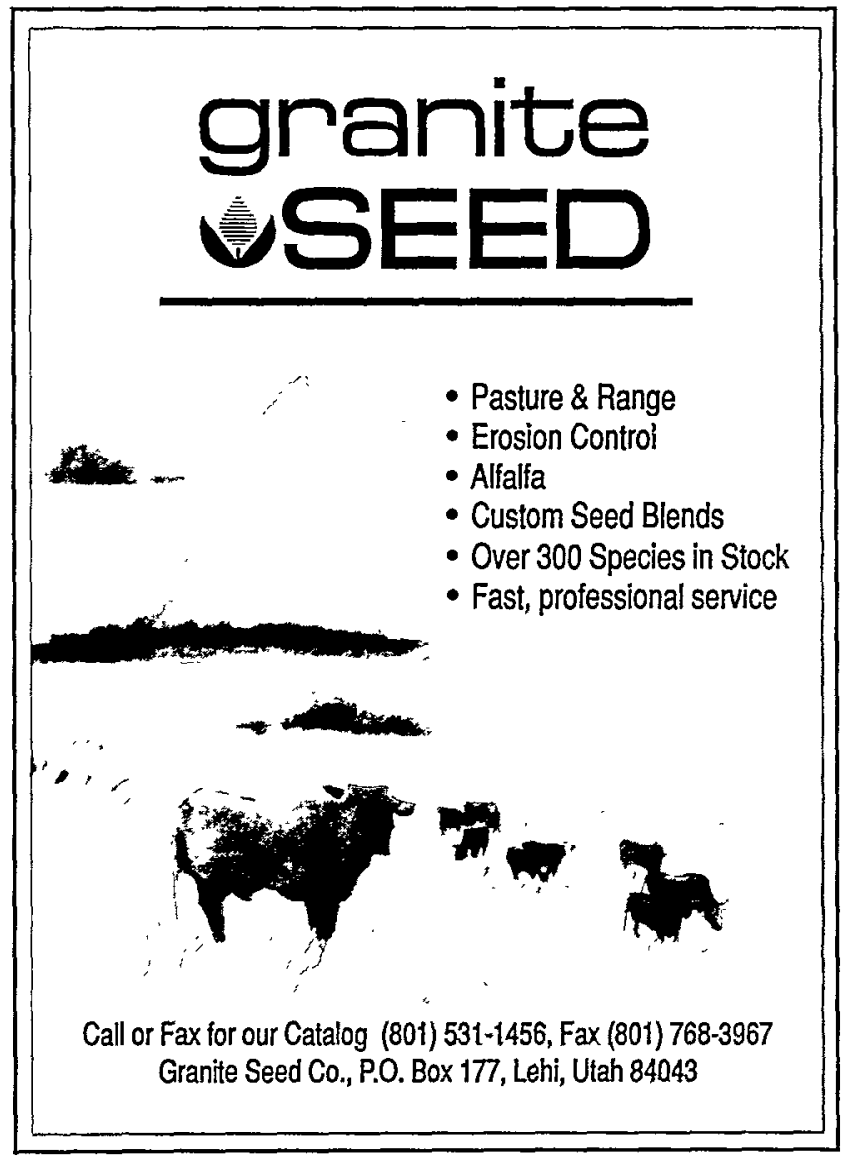

